\title{
Rebel Discourse(s) on Gender as Demonstrated by Contemporary and Historical Chinese Marriage Practices
}

\author{
Casper Lötter \\ https://orcid.org/0000-0001-7787-1419 \\ North-West University \\ casperlttr@gmail.com
}

\section{Abstract}

I attempt to evaluate rebel discourse(s), as opposed to mainstream, dominant discourse, on gender as demonstrated by marriage practices in Chinese societies, both contemporary and historical, vis-à-vis general Western, marriage practices. This is done discursive-analytically by way of cross-cultural analysis as methodology. Contributions on the theory of discourse are considered and applied. In this contribution, several rebel discourses on marriage during both post-Maoist Peoples' Republic of China (PRC) and former dynastic periods, are found to be emancipatory (with women refusing to partake in patriarchal constructs such as marriage) and progressive (with women having several sexual partners simultaneously). The hope is expressed that the profound insights unearthed from these rebel discourse(s) might be beneficial for Western feminisms. To this end, I utilise Zwart's notion of cultural "mixing" and Derrida's idea of the "sliding signifier" before making recommendations for improved public policy formulation. If the 21 st century is indeed the Chinese century, such investigations are crucial.

Keywords: emancipation; cross-cultural analysis; marriage; rebel gender discourse(s); Peoples' Republic of China (PRC)

Sex is a status category with political implications. (Kate Millett 1989)

There is a crack, a crack in everything. That is how the light gets in. (Leonard Cohen 1992)

\section{Introduction}

I consider three seminal ideas that are embedded in rebel discourses on gender in contemporary and historical Chinese marriage practices since ideas, as Derrida (1982)

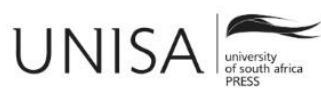




\section{Lötter}

said famously, are structured in both time and space. Dominant or master discourse, as Bourdieu (1977) points out, is invariably shadowed by rebel discourses, and this is as true for gender as for any other topic. These customs are gauged vis-à-vis South African marriage practices. In our multi-polarised, twenty-first century (Frankopan 2015; 2018; Jacques 2012; Morris 2010; Zakaria 2011), Asian concerns (particularly those of China, India or both) are increasingly likely to trump Western values.

In this regard, it is often thought amongst intellectual circles in the West that profound ideas on women's liberation emanated or emanates almost exclusively from feminist texts produced in the West. This Eurocentric bias is not entirely unfounded, since the West has been the dominant civilisational apparatus for the past half a millennium. I attempt, however, in this contribution to demonstrate that other non-Western cultures have also come up with important ideas that could enrich Western feminist practices. By way of example, Michael Wood $(2020,438)$ argues in his excellent one-volume history of China, that, speaking of China, "there had been a circulation of feminist ideas among women artists, poets and writers over many centuries; speaking within the constraints of the culture but finding ways to publish their feelings and ideas [my emphasis]." Rebel discourses are of great interest to feminists.

Perhaps these rebel discourses, valuable as they certainly are, could guide our Western sensibilities in structuring an emancipatory space for women to seek their "gender configuration" unencumbered by the distortions inherent in male discourse. Add to this, the normalisation of "gender conversion therapy" in this sexually conservative society with deeply entrenched gender inequities, and we have the makings of a patriarchal society not incomparable to South Africa.

Although South Africa has been labelled as one of the most dangerous countries in the world (Institute for Economics and Peace 2018), present-day China has its own disturbing statistics on femicide (Law and Liu 2008; McLoughlin, Gould, and Malone 2015; World Health Organisation 2009). ${ }^{1}$ Femicide is understood as either infanticide or suicide in later life. As recently as December 2020, the Shanghai-born, New Yorkbased gender activist and journalist, Jiayun Feng (2020a), lamented "the pervasive problem of violence against women in China." The high incidence of female suicide, noted above, has attracted the attention of China scholars and at least one (Wolf 1975, 111) has seen this social movement as a form of rebel discourse against oppressive social practices. She argues that "it made [and makes, since it is on-going] a strong statement about the status of women [in Chinese societies]."

Since sex is a status symbol with political implications, I have selected marriage customs as a suitable topic, as marriage has been identified as an "ideological trap" for women, both in the East and the West, and moreover one from which few Chinese

1 Although most of these sources are older than 10 years, there is regrettably nothing more recent. 


\section{Lötter}

women have been able to escape over the past few millennia. I read the idea of marriage, understood as the notion of the nuclear family unit, through the prism of what Giyatri Spivak $(1981,183)$ has called "the uterine norm of womanhood [that] supports the phallic norm of capitalism." Maria Mies and Vandana Shiva $(1993,14)$ have elaborated on this insight and explain:

We see the devastation of the earth and her beings by the corporate warriors, as feminist concerns. It is the same masculinist mentality which would deny us our right to our own bodies and our own sexuality, and which depends on multiple systems of dominance and state power to have its way.

The monstrous link (namely, a warrior mentality) between the exploitation inherent in neo-colonial capitalism and the subjugation of women almost everywhere (effectively through the construct of marriage), is carefully highlighted in the passage quoted above.

The discussion in this contribution is structured around six argumentative steps: Firstly, I briefly overview Lacan's and Bourdieu's theorising on discourse. Secondly, I introduce cross-cultural analysis as a research methodology, informed as it is by gender as a research tool within a contemporary Chinese context. Thirdly, as cross-cultural analysis is based on three complementary notions, I will describe these concepts. Fourthly, I consider the idea of cultural "mixing" as a credible method for transplanting ideas from one culture to the next. Fifthly, I argue that at this point we are in a position to consider and gauge three rebel discourses on gender, insofar as marriage practices both contemporary and historical among the Chinese peoples are concerned. In conclusion, the hope is expressed that seminal ideas on women's emancipation from the crushing yoke of patriarchal oppressions could improve efforts in the West to ameliorate women's conditions in this part of the world. I proceed accordingly to consider Lacan's and Bourdieu's thinking on discursive types, as these are formatted by different forces.

\section{Lacan and Bourdieu on Discourse Formation}

Foucault $(1978,95)$ formulates the notion of the relation between dominant and rebel discourse in the following striking words, namely that, "where there is power, there is resistance," although we need not heed his rider (which is that resistance is futile). Other important contributions to the theory of discourse were made by Bourdieu and Lacan, among others.

According to Bourdieu (1977, 164-5), the distinction between "orthodox" and "heterodox" (corresponding to Lacan's master and hysteric discourses respectively) answers to the discursive mainstream and subversive formations found in any contentious debate. Heterodox or rebel discourses on any such issue appear both on the left and right of orthodox discourse. Bourdieu (1977) suggests that these rebel or heterodox discourses might conceivably remain "in doxa" (on the outside of public discourse) until social, political or economic crises force them into the open, disturbing 


\section{Lötter}

our settled convictions embedded "in habitus [sic]." Habermas makes a similar observation in his well-known work on the so-called "life world" (Lebenswelt). Thakur $(1997,61)$ puts this issue in terms of the notion that whereas a great many possible positions or opinions exist resisting hegemonic discourse, because such stances have not yet been articulated, they cannot enter institutionalised discourse. This implies that rebel or heterodox discourses can indeed become orthodox themselves if they are able to enter mainstream thinking, as indeed happened with Marxism/communism in Eastern Europe and elsewhere after World War II.

Lacan $(2007,13)$ added to these insights on the nature of discourse. He understands discourse as being a "naturalising" exercise that constitutes subjectivities and sets the scene for the interplay between the four different discursive trails. In contrast to the master and slave, which present a smooth, uncomplicated version of reality, the third and fourth discourses of hysteric and analyst critically respond by revealing the "cracks" (as Leonard Cohen [1992] notes in the prelude) in this dominating narrative. Whereas the hysteric points out the inconsistencies in mainstream discourse (represented by the master and slave duo), the analyst's discourse (Lacan 2007, 13eff) illuminates the master's coercive parameters upon the individual's life. The analyst attempts to mediate between hysteric, master and university (also known as the slave); such analysis allows for a more flexible master discourse to emerge, making for easier interrogation by the hysteric. The perceived inevitability or weight of the subject's life course projection is bracketed by the hysteric and mediated by the discourse of the therapist.

In this respect, Habermas $(1984,358 ; 1987,3-42)$ commends the hunt for possible emancipatory practices/institutions in all cultures (including the Occident and the Orient), both past and foreign. Taking my cue from Habermas, this is exactly my intention with the writing of this paper.

In the Chinese context, the well-known British sinologist, Raymond Dawson (1967), demonstrates in The Chinese Chameleon: An Analysis of European Conceptions of Chinese Civilization (1967), his seminal work on Oriental discourse formation happening on both conscious and visceral levels, that:

European understandings of China (including those European diaspora traditions found in the United States and Australia) are multifaceted. These are as much shaped by objective issues in China as by the various "mirrors" that reflect Europeans" own prejudice and obsessions (both conscious and unconscious), with the Chinese as an exotic outpost in an alien landscape. (Lötter 2020)

It is worth noting that Dawson's (1967) plausible and credible account of these "multifaceted" Orientalist discourses - sprouted in the European mind by the objective and subjective perceptions of the Chinese chameleon on the other end of the vast Eurasian continental landmass - appeared a good decade before Edward Said's famous text Orientalism (1978). Said's text ostensibly deals with the same topic, though the latter 


\section{Lötter}

seems to focus on the Middle Eastern/Islamic world. Jayawardena (1986, 174-175) suggests that foot-binding and femicide are the two most enduring "Orientalist" discourses on China to circulate in the West, even at the tail-end of the twentieth century. These myths demand intellectual vigilance to grasping their significance in their peculiar cultural context. Against the backdrop of this discussion on the theory of discourse, I consider accordingly cross-cultural analysis as a research methodology amidst gender as its centrepiece.

\section{Cross-cultural Analysis as a Research Methodology}

Cross-cultural analysis is a methodology of sound professional standing that has been designed to make epistemological and ontological sense of cultural borrowing from one cultural setting to the next. Emily Martin $(1989,4,11)$ has explained this idea by suggesting that it is almost impossible to judge one's own culture because of its overwhelming familiarity. Said differently, such cultural comparisons might reveal elements in the researcher's own culture that may have otherwise remained hidden. Accordingly, Lisa Heldke $(2002,111)$ defines this method as "exploring and evaluating concepts and practices from a culture other than one's own, using tools from one's own culture."

Within the context of cross-cultural analysis as a research methodology, feminists have made the case for gender as a tool of analysis par excellence. Helen Haste (1993, 107, 101) suggests that few avenues of inquiry reveal such "complex and deep-seated resistances" to change as do traditionally fixed gender categories, and she argues for innovative ways in which to question existing gender configurations. Gender, as a research tool for feminist cultural analysis, has been justified in the following persuasive terms:

Unlike race, ethnicity, nation, or religion, gender is not a domain. It is a system of difference that has not been the basis of social groupings of likeness. Yet, gender pervades all these domains, and this is why we think feminist cultural analysis is especially crucial for rethinking them. If holiness is about keeping categories separate, then feminist cultural analysis could be considered sacrilegious, because we are breaking a taboo by reading across culture. (Yanagisako and Delaney 1992, 20)

It is for this reason, among others, that Yanagisako and Delaney $(1992,20)$ contend that cross-cultural analysis, with a bias privileging the perspectives of women, has a special critical edge to it. In this respect, the prominent Chinese feminist Li Xiaojiang 李小江 $(1999,262)$ argues that in terms of trans-national theory, the Western concept of gender as a social category, rather than a biological one produced by second-wave Western feminism (1968-1978), is the result of post-Enlightenment European thought, and should not be transported into Chinese languages. This demarcation between social gender as opposed to anatomical sex was already implicitly understood in Chinese culture well before the early 1900s. Against this contemporary Chinese context of 
feminist cultural analysis, I proceed to consider the three complementary notions upon which cross-cultural analysis is based.

\section{The Three Notions}

Cross-cultural analysis, with its sharp feminist edge, as noted above, is a reading strategy aimed at: 1) revealing culture's normalising tendency to fuse oppressive and opposing discursive trends by way of; 2) a contextualised reading; 3) against the grain. By reading against this cultural grain of "normality" the task of a cross-cultural feminist analysis is to reveal a culture's tendency to edit contradictory (and oftentimes oppressive) discourses into a seemingly cohesive social structure (Yanagisako and Delaney 1992, 15-19). This reading strategy aims to demonstrate that cultural practices and discourses are not premised on inevitability and do indeed have historical origins (Yanagisako and Delaney 1992, 9-14). One effective way to accomplish this task is to put contradictory discourses in conversation with one another. Finally, such reading must not take place in vacua, but needs to be contextualised so as to take "into account specific systems of classification and meaning" (Yanagisako and Delaney 1992, 20) based on a sound understanding of the practices, institutions and discourses (invariably conflicting) at stake in the culture(s) under consideration.

In the post-Marxist tradition of a critical theory of society, Habermas $(1984,132)$ has drawn attention to the importance of the "hermeneutical sensitivity" of such cultural reading - followed by the need for a critical assessment from the "outside" of "the reasons from the inside" (Habermas 1990). Even if one disagrees with the universal application of hermeneutics, Habermas's observation, astute as it certainly is, might be of greater application to dominant, socially approved discourses than to the rebel variety I concern myself with in this contribution. In the final analysis, my aim with this exercise is to imagine a cultural "mixing" of sorts between ideas derived from these Chinese rebel discourses on marriage practices with local customs. To this end, I turn my attention to a brief consideration of Tom Zwart's explanation of the receptor approach.

\section{The Receptor Approach}

Cultural integrity is pivotal to the receptor approach, as the latter aims to resonate with the receiving culture's internal logic. Instead of risking raising possible decolonisation objections to Western alternatives, the receptor approach encourages "home-grown remedies" in the proposed transplantation of ideas from one cultural context to the next (Zwart 2012, 546-547). The rationale is that innovations are more likely to have their utilities more greatly realised in a fresh context by their interweaving with established local practices.

Zwart $(2012$, 559) argues persuasively that "the remedy should be tailored to this rationale." By way of example, boys in Islamic Africa might publicly undertake to 


\section{Lötter}

betroth uncircumcised girls only, which is a gesture likely to make inroads into the entrenched localised custom of shunning the latter and showing a partiality for circumcised girls (Zwart 2012, 559). Another example is FAMSA (Family South Africa, an NGO) encouraging women trapped in abusive relationships to empower themselves economically, through the acquisition of skills towards small business entrepreneurship as a way to escape from these circumstances (Zwart 2012, 557). A remarkable South African innovation was the idea of combining the indigenous shamanic beliefs with Western medicine, which succeeded in rolling back the HIV/AIDS pandemic to some extent (Liddell, Barrett, and Bydawell 2005; Wreford 2009).

Another way of adding value to an "already existing and operative indigenous system" without throwing out the baby with the bath water, is the "fusion" of different cultural practices, by acknowledging the complexity of concrete instances in terms of a "both/and" understanding. Bert Olivier (2013) suggests that post-structuralism's profound advantage lies in its ability to merge the best of two disparate worlds "by thinking them together." Against this backdrop, I believe we are now in a position to consider with profit the three rebel discourses on gender, noted in the introduction, as demonstrated in Chinese marriage practices. I begin with the idea of polyandry as a practice to improve the status of women.

\section{Polyandry as a Practice to Improve the Status of Women}

In June 2020, Yew-Kwang Ng 黄有光, a Malaysian economist appointed as visiting professor of economics at Fudan University in Shanghai, succeeded in generating a great deal of ire on Chinese social media after publishing an article (in Chinese) advocating for the legalisation of polyandry to ease the mainland's crushing gender imbalance of 117 males to 100 females. So-called "bare branches" (光棍 guānggùn), calculated to be at least 34 million on the mainland, have resulted from a wide-spread cultural predilection for boys compounded by, until fairly recently (2015), a government campaign encouraging the one child-policy (Feng 2020b). Ng further attempted to justify his argument by suggesting that single men supporting prostitution on a tight budget is not a feasible proposal. Some irate women suggested that the experiment should start with his own daughter (!), a proposed male infanticide and berated him for claiming that Chinese women should serve as prostitutes or "sexual vessels" for Chinese men (Feng 2020b).

Nicola Heath (2018) clarifies the difference between polygamy, polygyny and polyandry in the following illuminating terms:

It is important to note that when we talk about polygamy, often what we're really talking about is polygyny - where a man takes more than one wife. Polyandry, where a woman takes more than one husband, is a much rarer practice. The frequent disparity in marriage rights given to men and women in countries that permit polygamy is one of the reasons 


\section{Lötter}

the United Nations Human Rights Committee recommended in a 2000 report that polygamy be outlawed.

Despite the vehement reaction from Ng's female audience and even though Heath, in the passage cited immediately above, asserts that polyandry is a "much rarer practice" than polygyny, the former was widely practiced in Qing China during the eighteenth and nineteenth centuries. Before its liberation by the Chinese People's Army in 1950, when it was outlawed, polyandry was practised on an extensive scale in Tibet (Feng 2020b). Significantly, its practice in rural China during the High and Late Qing was also challenged by the state.

Matthew Sommer (2015) contends, based on his extensive investigation of court records during China's last dynasty in his scholarly work on polyandry in Qing China, that poverty drove many families in rural areas in many Chinese provinces to invite another man to pool resources and "join" the family to avoid financial hardship. This was, and is, an attractive alternative to wife-selling or prostitution (also wide-spread in both Qing China and the contemporaneous PRC) as these initiatives impinge on women's autonomy and status. This observation is supported by the many records of women's active participations in the negotiations to finalise their polyandrous contractual arrangements. Arrangements of this sort were often made to preserve the family and to give the newcomer a refuge from homelessness or poverty or loneliness. An illuminating example quoted by Sommer (2015) is the case of Zheng Guoshun and his wife, Jiang Shi. When Zheng went blind, his wife invited a younger man called Jiang Yilang (no relation of hers) to move in and help out on the farm. Significantly, this arrangement took place in the rural southern province of Fujian in the mid-1700s and the newcomer's labour was exchanged for sex with the wife — an arrangement which lasted 28 years until Zheng Guoshun passed away. According to historian Ted Telford (quoted in Mardenfeld [2020]) the "marriage crunch" during Qing China made the practice of polyandry quite acceptable in lower-income communities, but taboo among the social elite where, ironically, polygyny and female infanticide were rife.

Although Zheng Guoshun and his wife, Jiang Shi's, arrangement with Jiang Yilang by all appearances suggests a fairly harmonious situation, many other examples quoted by Sommer (2015) show that animosity and jealousy often got the better of the participants involved. Reference (2020), for example, suggests that "[t]he vast majority of polyandrous marriages involved a woman who married two or more brothers. Known as fraternal polyandry, this process was considered more stable than nonfraternal polyandry, the marriage of one woman to several non-related men."

Perhaps marrying two brothers (India and Nepal having many documented examples) is a solution of sorts to avoid the more extreme cases of jealousy. It must be kept in mind that the practice of polyandry during Qing China nevertheless took place within a deeply entrenched patriarchy, and that such a cultural setting was clearly not ideal for 


\section{Lötter}

polyandry to flourish. What is instead called for is a feminist perspective in which women are seen as human beings. As Spivak $(1981,183)$ points out, marriage in patriarchy is based on the exploitation of women as stereotypical (m)others for the benefit of male-centred capitalist ventures. Polyandry is a lovely idea to diffuse this reprehensible construct as this is a feasible way to level the playing fields, especially on a visceral level.

Although polyandry is forbidden by the West and all three monotheistic religions (Christianity, Judaism and Islam), in the contemporary world, it is still practised in India, Nepal, certain provinces in China, parts of East Africa, Amazonian South America and parts of Nigeria (Heaphy n.d.). Heath (2018) is also wrong to uncritically quote the United Nations report recommending that polygamy should be criminalised. In fact, the evidence suggests that, whereas the practice of polygyny confers inferior social and economic status upon women, the opposite is true for polyandry-where women are permitted to own property and are better respected. Ng's inept attempt to justify this practice in 21st century mainland China should not detract us from considering whether or not this proposal nonetheless has great emancipatory potential, from a feminist perspective, to elevate the status of women in a patriarchal world-order rife with misogyny and gender-based violence. In the wise words of Patricia Ebrey (1993, 262-263),

Whereas men could openly celebrate taking a new wife after their first had died, women who remarried often felt bad about themselves for entering into a sexual union with a second man. Similarly, while most men viewed the taking of concubines as one of life's pleasures, wives typically saw it as a trial. Men viewed women's intense jealousy as a mental aberration, like illness or possession; the women, however, were more likely to focus on their husbands' blindness to the manipulativeness of the concubines.

This stark difference in perspectives between Chinese men and women, so eloquently explored for us by Ebrey, underscores the deeply entrenched gender inequalities embedded in a patriarchal society. By reversing the orthodox position(s)—women having more than one husband or lover simultaneously - this small feminist advantage could problematise that mindset of assumed male privileges, such as access to concubines over and above a wife, if only on a peripheral level. I argue that these considerations favouring polyandry are important ideas in a post-modern world combatting teeming misogyny and rampant gender-based violence against women. If polyandry allows women more room for financial and economic survival, I argue that nü shu is a practice aimed at allowing women exclusive space to pursue female subjectivities without any intrusive and pervasive male presence.

\section{Nï shu (女书) as a Practice to Allow Women Exclusive Space}

Peter Zarrow $(1988,796)$ argues that "[p]erhaps feminist movements in modernising nations go through parallel, overlapping stages." If there is one opinion with which all 


\section{Lötter}

of transnational feminist theory agrees in a world of patriarchal ideology demanding conformity, it is the disapproval centred on the female stereotype. In the apt words of Patricia Ebrey $(1993,262)$, mulling over the conclusions she drew from her scholarly text on the lives of Chinese women during the Sung dynasty:

If we knew more about women's conversations out of the presence of men, we could undoubtedly point to many more cases of inconsistency, tension, or ambiguity. In such a cultural environment, women had room to appropriate parts of the general culture to their own benefit and to fashion ways of thinking and acting that gave them some real sense of purpose and self-worth.

One of these areas of exclusive spaces is that of the secret language of nü shu. On 20 April 2002 the following notice appeared on BBC's Women's Hour International Archive (2002):

China is planning to spend a million dollars to save what's believed to be the world's only language used exclusively by women. It's only found in one tiny area of Hunan province and was used by secret sisterhoods for probably around a thousand years. Nü Shu, as the script is called, was preserved on fans and silks.

Nü shu literally means "women's script." I suggest that spaces occupied by women exclusively, as is the case with nü shu, are important sites for women to come to terms with their own subjectivities. Tani Barlow $(2002$, 156) proposes that film and its commentary provide one arena where "the still unpredicated female subject" expresses an intense desire to search for room to be a woman beyond the "damaging codes of masculine gender performativity." In an age of unprecedented crisis in masculinity, both in the East (Marchetti 2006, 17-19) and in the West (Faludi 1999), affordable travel and cross-cultural/transnational "screen culture" have opened up tremendous opportunities for women seeking safe spaces. Moreover, as Lisa See $(2011,337)$ informs us, the PRC has reversed its previous stance on nü shu and "now considers nü shu to be an important element of the Chinese people's revolutionary struggle against oppression." During the Cultural Revolution, nü shu was almost wiped out as the Red Guards considered it to be a reactionary force and a great many precious instruments (fans, documents, silks) were destroyed (See 2011, 335-336).

As Bourdieu (1977) indicates, this is an example of an idea in doxa which has finally entered the mainstream, dominant culture after having been a rebel discourse for a thousand years. It is through the filmic adaption of See's novel by the same title, Snow Flower and the Secret Fan (2011), directed by Wayne Wang, that I first became aware of the existence of nü shu. Safe spaces for women, as the still unpredicated female subject, certainly do not include the constrains of traditional Confucian marriages. As Colleen Hall (1988, 77n44) contends, nature's purpose need not be ours. Cantonese women and their engagement with sericulture appear to have successfully challenged patriarchy on this score for at least 100 years. 


\title{
"Delayed Transfer Marriage" as a Way to Dilute Marriage as a Patriarchal Practice
}

In exploring the difference between nationalism and women's concerns, Zarrow (1988, 796) argues that this demarcation was well understood by Chinese anarcho-feminists even before the onset of the 1911 revolution:

\begin{abstract}
Anarchists publishing in small student journals in the years before the 1911 Revolution made a significant contribution to Chinese feminism. They linked feminism to their call for a complete social revolution; they understood the oppression of women in China to be linked to modern class divisions and economic exploitation as well as traditional culture. They discussed the relationships among feminism, individual rights, and political liberties. He Zhen in particular severed feminism from nationalism, proclaiming "women's liberation" not "for the sake of the nation" but out of moral necessity.
\end{abstract}

One such issue that remained shrouded in controversy, is marriage. The reproductive capacities of women have always been politicised in order to ensure that they produce the manpower to fight the state's wars, if need be. In the tug-of-war between feminists and the state, marriage is bound to remain contentious. Indeed, as Harriet Evans (2008, 84) puts it, "[t]he limits of the transformative possibilities of [Chinese] femininity were [sic] defined by the women's 'natural' capacities, responsibilities and interests." Of particular interest to feminists are the ways and the extent to which women have been able to avoid marriage, especially in a sexually conservative society such as mainland China.

Marriage practices in China were certainly never immutable. Patricia Ebrey $(1993,66)$ suggests that " $[\mathrm{w}]$ hatever the explanation or combination of explanations, the change from Northern to Southern Sung is further evidence that marriage practices were subject to change."

There is sufficient evidence to conclude that this happened for the betterment of women in the case of the Canton Delta for at least 100 years during the nineteenth century and into the twentieth. In striking contradiction to traditional Confucian marriage, Janice E. Stockard (1989) argues in her scholarly account of the so-called "delayed transfer marriage" practices in the Canton Delta, that the dominant alternative practice was for the wife to stay with her own parents for a period of three years after the marriage ceremony. Although the new bride was required to visit her husband on festival occasions, she was not expected to fall pregnant until the three year-delay transfer had run its course. The reason for this extraordinary arrangement is the significant economic independence that employment in silk-reeling factories gave young women. "Delayed transfer marriage" practices accordingly occurred in the rich silk-producing district of the Canton Delta as well as adjacent rice-producing areas. Patricia Ebrey $(1993,148)$ suggests that "[t]he social approval given to these activities [splicing, spinning and 


\section{Lötter}

weaving] undoubtedly relates to their femininity (they were women's work) and their domestic location (women did not need to come into much contact with men to perform them)." Such significant economic independence also led to other radical alternatives to the traditional Confucian marriage (Chow 2005, 599; Cohen 1970, 434, 436-437; Ebrey 1993, 50-53; Thakur 1997, 35-36), such as compensation marriage, spirit marriage or sworn spinsterhood.

A compensation marriage allows the bride to compensate her husband financially for her absence, which allows him to acquire a second wife, while the first wife need only return to her husband later in life to live with him. A spirit marriage allows young women to marry the spirit of a deceased young man who had never married, giving the former the benefits of marriage and independence from a potential husband. Finally, the practice of sworn spinsterhood was a radical option that allowed young women to vow to remain spinsters, rejecting marriage altogether and embracing a self-supporting lifestyle. Even though Patricia Ebrey $(1993,149)$ argues that she had been unable to observe any evidence of the benefits of sericulture, I suggest that the examples quoted by Stockard (1989) of the radical alternatives to marriage open to young marriageable women, are proof indeed of the benefits, both financially and emotionally, which the presence of sericulture bestowed upon women.

I argue that the system of "delayed transfer marriage" was an innovative way to dilute marriage as a patriarchal construct, and to repurpose it as a vehicle for women's emancipation. For this reason, and others, I cannot agree with Elisabeth Croll's (1978, 44) observation that "they [delayed transfer marriages] remained at the level of rejection and furnished a form of escapism rather than a significant force for change." In the wise words of Michael Wood (2020, 438), quoted in the introduction to this paper, women spoke "within the constraints of the culture but [nevertheless] finding [sic] ways to publish their feelings and ideas." By way of example, Patricia Ebrey $(1993,8,263)$ has stressed the role of agency for improving Chinese women's lives despite the odds, and that "[e]mphasising women's victimisation, in other words, only tend to obscure what women were able to accomplish." To call such courageous rebellion "a form of escapism rather than a significant force for change," as Elisabeth Croll does, is disrespectful, incorrect and amounts to nothing if not Foucauldian neo-conservative resignation. As Harriet Evans $(2008,87)$ argues:

Even though alternative perspectives are obscured by the normalizing power of the party-state to erase different interpretations of its past and present, they are nonetheless a living reminder of the disruptive potential of local cultural narratives to challenge the subjectifying terms of the dominant renderings of the modern.

By analogy, I contend that the alternate potential of delay-transfer marriages in nineteenth-century Canton Delta has a similar power to disrupt dominant discourse on gender-both in the PRC (removed in time) and South Africa (twice removed, in time and space [Derrida 1982]). 


\section{Discussion}

At the outset of this contribution, I remarked that I intended to read Chinese rebel discourses on gender as they have manifested in marriage practices, both historical and contemporaneous, through the prism of the post-colonial feminist Giyatri Spivak's (1981, 183) view of marriage as modelled on "the uterine norm of womanhood [that] supports the phallic norm of capitalism."

In my reading, all three rebellious discursive movements on gender, as embodied in marriage, have been important and innovative instruments in showing up marriage for what it is - an oppressive, unworthy ideological trap for women (Firestone 1979; Rich 2003; Rubin 1975) — while at the same time showing a plausible, if uncomfortable, avenue for either repurposing marriage (such as with delayed-transfer marriages) to allow more freedom for women or for reversing the inherent male privileges embedded in marriage as a patriarchal construct. An example of the latter is the case for polyandry rather than polygyny. Polygyny, as is generally well-known, is a practice wellentrenched in Africa in general and in South Africa in particular. At least one of South Africa's post-Apartheid presidents, Jacob Zuma, has multiple legal wives and also an untold number of girlfriends. The point is that Zuma's participation in polygyny (the opposite of polyandry), especially to the extent to which he practices it, perpetuates the violence inherent in patriarchy, particularly in such a misogynistic country like South Africa replete with gender-based violence. Instead, I argue that legalising polyandry and/or encouraging this (rebel) institution as an acceptable cultural practice would correct this currently substantial power imbalance that favours men over women in South Africa's sexual and gender conservative society. This is, to say the least, a disgrace in a democratic country that is founded on non-racialism, gender-equality, individual autonomy and personal dignity.

Be that as it may, no discourse, certainly not this extremely patriarchal idea in the South African context, is all-consuming, and Lacan's (2007) discourses of the hysteric and the therapist have indicated how the master's view could be problematised and redirected for emancipatory purposes.

Although some of these heterodox discourses in the Chinese context, such as female suicide, may appear to be very destructive from a Western perspective, it must be remembered that even in the West, women and mental disease are second cousins (Chesler 2005). This is primarily because women live in a dystopian society distorted, among other forces, by bruising male discourses (Perez 2019). In the Chinese setting, female suicide is not so much the result of mental disease, but rather a sign of social protest against unbearable conditions of patriarchal oppression, when no other reasonable avenues seem to be available. Women's agency, for which Ebrey (1993), Wood (2020) and Evans (2008) have made such a compelling case, decidedly has limits of endurance. 


\section{Lötter}

In general, I argue that careful study of rebel discourses on gender in (a) non-Western culture(s), such as that of the Chinese peoples, both past and present, has rendered much evidence to consider in enriching our own gender paradigms. "So deeply embedded is patriarchy," Kate Millett $(1989,63)$ wrote, "that the character structure it creates in both sexes is perhaps even more a habit of mind and a way of life than a political system." In view of patriarchy's successful tendency to naturalise power relations, as Millett suggests, a cross-cultural analysis with a trans-national feminist reach, is imperative. By considering Derrida's $(1982,317)$ inter-contextual transplantation of ideas (his "sliding" of the "signifier") together with Tom Zwart's receptor approach (2012), I make a few recommendations likely to enrich South African gender practices.

I am mindful of Colin Crouch's $(2004,4)$ warning that policy formulation in an era of so-called "post-democracy" means nothing if "[b]ehind this spectacle of the electoral game, politics is really shaped in private by interaction between elected governments and elites that overwhelmingly represent business interests." As a result, I aim my remarks at individuals with a certain level of social conscience and NGOs intent on gender activism.

Women need role models to emulate. By way of example, in her concession speech in 2016, after losing the Presidential race (though she won the popular vote) to Donald Trump, Hillary Clinton (2016) apologised touchingly to all the little girls who had been robbed of a role model. To this extent, it is a worthwhile idea for female public figures of a certain stature, as has happened in China recently by the internationally acclaimed dancer Yáng Lìpíng 杨丽萍 and the Chinese actress Qín Lán 秦岗 (Feng 2020c), to publicly disown marriage as a trap for women and deny the apparent benefits of motherhood (although, admittedly, not all women stand averse to motherhood). These public platforms, as the Chinese experience has shown, can be used effectively to shift cultural expectations and, indeed, horizons. Polyandry as a cultural practice in Africa is also not unknown, as I noted above, and gender activists in South Africa in particular, could ventilate this idea as an innovative emancipatory construct to challenge cultural notions of the possible. This feature of indigenous African culture is likely to enhance the cultural legitimacy of this idea. In order to achieve this, as I have argued, women need safe spaces to ponder their as yet, unforeseeable and still unfolding subjectivities.

In Ammonite (2020), directed by Francis Lee, the safe space which the (mostly) overlooked British palaeontologist Mary Anning (Kate Winslet) creates for the young wife Charlotte Murchison (Saoirse Ronan), entrusted in her care, allows for Charlotte's emotional, physical and spiritual healing once she had been released from the damaging environment of her husband's gender performativity. Judged by The Guardian to be "one of the finest films of the year," the film is based on a true account of their passionate and all-encompassing love affair. On second thoughts, the safe space generated by the interaction between these two women, leads to love, healing and happiness in both their lives. 


\section{Lötter}

Finally, from a trans-national feminist theoretical perspective, mindful as I am of the pitfalls of both cultural relativism and Orientalism, I suggest that a contextualised reading of these rebel discourses on gender against the cultural grain of dominant Han Chinese culture, has exposed its normalising tendency. I also contend that more studies such as embodied in this contribution are needed to empower women everywhere, especially in our globalised world with a powerful social media and internet network.

\section{Conclusion}

In this contribution, several rebel discourses on marriage, both in post-Maoist PRC and former dynastic reigns, are found to be emancipatory (refusal to partake in patriarchal constructs such as marriage or repurposing the idea of marriage in innovative ways to promote women's freedoms of intimate association) and progressive (women having several sexual partners simultaneously). I argue that investigating rebel discursive movements on gender is important because the ideology of controlling women's reproductive choices and sexual economy is essential for a patriarchy focused on ravaging the earth's resources (be it on the backs of subjugated females), as Mies and Shiva (1993) point out. To this end, marriage is the perfect vehicle in which to store women's reproductive and sexual potential as a standing reserve. Marriage demands interrogation, since it is a political institution with far-reaching patriarchal and neocolonial capitalist roots.

Moreover, even in a century likely to be dominated by non-European concerns, it is only by learning from own our mistakes that we can re-group effectively and make a more concerted effort to improve society. In the well-known words of Samuel Beckett, "Try again, fail again. Fail better." Nonetheless, the Chinese theatre has produced fascinating rebel discourses on gender as demonstrated both in contemporary and historical Chinese marriage practices. Habermas's (1990) suggestion of seeking out emancipatory practices in cultures both past and foreign, is clearly a valuable one.

Western marriage practices do not seem to yield as well to the range of rebel discursive movements as does that of the Chinese peoples with their continuous 5000-year-old civilisation. The evidence from the Chinese experience seems to suggest that polygamous arrangements arose, for the most part, spontaneously as a result of economic or practical necessity - even if frowned upon by the elite and caused, at least in part, by the marriage crunch resulting from the latter's unapologetic perpetuation of the immoral practices of polygyny and female infanticide. An analogy could be made with the unattractive prospect of climate change, which has led to dangerous and unsustainable new weather patterns on the cusp of the twenty-first century and is the result, at least partially, of the behaviour of greedy industrialists in their having greenhouse gases released with scant regard for our environment - to the detriment of all living plant and animal life, especially the poor and the vulnerable. 


\section{Lötter}

For this reason, among others, the hope is expressed that the profound insights unearthed in rebel discourse(s) on marriage in non-Western cultures, such as those of the Chinese peoples, would be beneficial for Western feminisms, particularly in the South African human rights-driven context which favours a flourishing gender activist culture. I conclude that cross-cultural analysis with gender as its sharp, critical edge, has demonstrated itself to be a worthy methodology in unearthing brilliant insights from other cultures, which we might subsequently apply to the betterment of our own culture. If the twenty-first century is indeed the Chinese century, as it would in all likelihood seem to be, such investigations on gender practices are crucial.

\section{References}

Ammonite 2020. [Film]. Directed by Francis Lee. See-Saw Films, BBC Films and the British Film Institute: UK.

Barlow, T. 2002. "Picture More at Variance: Of Desire and Development in the Peoples' Republic of China." In Feminist Post-Development Thought, edited by K. Saunders, 146158. London: Zed Books.

BBC's Women's Hour International Archive 2002. "Nu Shu.” April 20. Accessed December 26, 2020. http://www.bbc.co.uk/radio4/womanshour/2002_17_sat_01.shtml.

Bourdieu, P. 1977. Outline of a Theory of Practice. Translated by R Nice. Cambridge: Cambridge University Press. https://doi.org/10.1017/CBO9780511812507.

Chesler, P. 2005. Women and Madness, 2nd edition. New York City: St Martin's Press.

Chow, R. 2005. "Against the Lures of Diaspora: Minority Discourse, Chinese Women, and Intellectual Hegemony.” In Postcolonialisms: An Anthology of Cultural Theory, edited by G. Desai and S. Nair, 589-607. Oxford: Berg.

Clinton, H. 2016. "Full Concession Speech.” NBC News, November 9. Accessed December 29 2020. https://www.youtube.com/watch?v=Bcck7hr9Su8.

Cohen, C. B. 1970. "Experiment in Freedom: Women of China." In Sisterhood is Powerful: An Anthology of Writings from the Women's Liberation Movement, edited by R. Morgan, 433-470. New York: Vintage.

Cohen, L. 1992. [Music Record Album]. “Anthem.” In The Future. Columbia Graphophone Company: United States.

Croll, E. J. 1978. Feminism and Socialism in China. New York: Schocken Books.

Crouch, C. 2004. Post-Democracy. Cambridge: Polity Press. 


\section{Lötter}

Dawson, R. 1967. The Chinese Chameleon: An Analysis of European Conceptions of Chinese Civilization. New York: Oxford University Press.

Derrida, J. 1982. "Signature Event Context.” Translated by A. Bass. In Margins of philosophy, 307-330. Chicago: University of Chicago Press.

Ebrey, P. B. 1993. The Inner Quarters: Marriage and the Lives of Chinese Women in the Sung Period. Berkeley: University of California Press. https://doi.org/10.1525/9780520913486.

Evans, H. 2008. "Gender in Modern Chinese Culture.” In The Cambridge Companion to Modern Chinese Culture, edited by K. Louie, 68-90. Cambridge: Cambridge University Press. https://doi.org/10.1017/CCOL9780521863223.004.

Faludi, S. C. 1999. Stiffed: The Betrayal of the American Man. New York: HarperCollins Publishers.

Feng, J. 2020a. "Chinese Songs that Say 'Me Too."” SupChina, December 16. Accessed December 26, 2020. https://supchina.com/2020/12/16/chinese-songs-that-say-me-too/.

Feng, J. 2020b. "Should Chinese Women have Multiple Husbands?" SupChina, June 3. Accessed December 26, 2020. https://supchina.com/2020/06/03/should-chinese-womenhave-multiplehusbands/\#: :text=\%E2\%80\%9CPolyandry\%20has\%20a\%20long\%20history.

Feng, J. 2020c. "Year in Review: 2020's Biggest News Stories about Chinese Women." SupChina, December 17. Accessed December 27, 2020.

https://supchina.com/2020/12/17/year-in-review-2020s-biggest-news-stories-aboutchinese-women/.

Firestone, S. [1970] 1979. The Dialectic of Sex: The Case for Feminist Revolution. London: The Women's Press.

Foucault, M. 1978. The History of Sexuality, Volume I: An Introduction. Translated by R. Hurley. New York: Vintage Books.

Frankopan, P. 2015. The Silk Roads: A New History of the World. London: Bloomsbury.

Frankopan, P. 2018. The New Silk Roads: The Present and Future of the World. London: Bloomsbury.

Habermas, J. [1981] 1984, 1987. The Theory of Communicative Action. Translated by T. McCarthy. Two Volumes. Boston: Beacon Press.

Habermas, J. 1990. "The Hermeneutic Claim to Universality." Translated by J Bleicher. In The Hermeneutic Tradition: From Ast to Ricoeur, edited by G. I. Ormiston and A. D. Schrift, 245-272. Albany: State University of New York Press. 


\section{Lötter}

Hall, C. 1988. "Rape: The Politics of Definition.” South African Law Journal, no. 105: 67-82.

Haste, H. 1993. The Sexual Metaphor. New York: Harvester.

Heaphy, L. (n.d.). "Polyandry, the Practice of Taking Multiple Husbands." Accessed December 26, 2020. https://kashgar.com.au/blogs/tribal-culture/polyandry-the-practice-of-takingmultiple-husbands.

Heath, N. 2018. "Faith and Polygamy: Which Religions Permit Plural Marriage?" SBS, July 2. Accessed December 26, 2020.

https://www.sbs.com.au/topics/voices/culture/article/2017/01/17/faith-and-polygamywhich-religions-permit-plural-marriage.

Heldke, L. M. 2002. “Cross-cultural Analysis.” In Encyclopedia of Feminist Theories, edited by L. Code, 111-112. London: Routledge.

Institute for Economics and Peace 2018. Global Peace Index. Accessed December 16, 2020. https://www.hsdl.org/c/from-the-institute-for-economics-and-peace-2018-global-peaceindex/.

Jacques, M. 2012. When China Rules the World, 2nd edition. New York: Penguin.

Jayawardena, K. 1986. "Feminism and Revolutionary Struggles in China." In Feminism and Nationalism in the Third World, 167-195. London: Zed Books.

Lacan, J. 2007. The Other Side of Analysis: 1969-1970. The Seminar of Jacques Lacan, Book 17. Translated by R Grigg. New York: W. W. Norton.

Law, S., and P. Liu, 2008. "Suicide in China: Unique Demographic Patterns and Relationship to Depressive Disorder." Current Psychiatry Reports, no. 10: 80-86.

https://doi.org/10.1007/s11920-008-0014-5.

Li, X. 1999. "With What Discourse Do We Reflect on Chinese Women? Thoughts on Transnational Feminism in China." In Spaces of their Own: Women's Public Sphere in Transnational China, edited by M. M. Yang, 261-277. Minneapolis, Minnesota: University of Minneapolis Press.

Liddell, C., L. Barrett, and M. Bydawell. 2005. "Indigenous Representations of Illness and AIDS in Sub-Saharan Africa." Social Science and Medicine 60 (4): 691-700. https://doi.org/10.1016/j.socscimed.2004.06.020.

Lötter, C. 2020. "The Chinese Chameleon Reimagined in the Age of Covid-19." Mail \& Guardian, May 9. Accessed December 24, 2020. https://mg.co.za/coronavirusessentials/2020-05-09-the-chinese-chameleon-reimagined-in-the-age-of-covid-19/.

Marchetti, G. 2006. From Tain'anmen to Times Square: Transnational China and the Chinese Diaspora on the Global Screens, 1989-1997. Philadelphia: Temple University Press. 


\section{Lötter}

Mardenfeld, S. 2020. "Why 19th-century Chinese Women sometimes Had two Husbands." Grunge, November 20. Accessed December 26, 2020.

https://www.grunge.com/282479/why-19th-century-chinese-women-sometimes-had-twohusbands/.

Martin, E. 1989. The Woman in the Body: A Cultural Analysis of Reproduction. Milton Keynes: Open University Press.

McLoughlin, A. B., M. S. Gould and K. M. Malone, 2015. "Global Trends in Teenage Suicide: 2003-2014.” QJM: An International Journal of Medicine 108 (10): 765-780. https://doi.org/10.1093/qjmed/hcv026.

Mies, M., and V. Shiva, 1993. Ecofeminism. Halifax: Fernwood Publications. https://doi.org/10.5040/9781350219786.

Millett, K. [1970] 1989. Sexual Politics. London: Virago.

Morris, I. 2010. Why the West Rules for Now. London: Penguin Books.

Olivier, B. 2013. "Modernism, Postmodernism and Poststructuralism, the Difference." Mail \& Guardian Thoughtleader. Accessed January 9, 2018.

https://thoughtleader.co.za/bertolivier/2013/05/24/modernism-postmodernism-andpoststructuralism-the-difference.

Perez, C. C. 2019. Invisible Women: Data Bias in a World Designed for Men. New York: Abrams Press.

Reference 2020. "Which Countries Practice Polyandry?” March, 31. Accessed January 6, 2020. https://www.reference.com/world-view/countries-practice-polyandry-8bd1951429f0175a.

Rich, A. C. [1980] 2003. "Compulsory Heterosexuality and Lesbian Existence." Journal of Women's History 15 (3): 11-48. https://doi.org/10.1353/jowh.2003.0079.

Rubin, G. 1975. "The Traffic in Women: Notes on the 'Political Economy' of Sex." Accessed January 10, 2020. https://summermeetings2013.files.wordpress.com/2013/04/rubintraffic.pdf.

Said, E. 1978. Orientalism. New York: Random House.

See, L. 2011. Snow Flower and the Secret Fan. London: Bloomsbury.

Snow Flower and the Secret Fan (2011) [Film]. Directed by Wayne Wang. Chinese Mandarin and Korean with English subtitles. Big Feet Productions: PRC. 


\section{Lötter}

Sommer, M. H. 2015. Polyandry and Wife-Selling in Qing Dynasty China: Survival Strategies and Judicial Interventions. Oakland: University of California Press. https://doi.org/10.1525/california/9780520287037.001.0001.

Spivak, G. C. 1981. "French Feminism in an International Frame." Yale French Studies, no. 62: 154-84. https://doi.org/10.2307/2929898.

Stockard, J. E. 1989. Daughters of the Canton Delta: Marriage Patterns and Economic Strategies in South China, 1860-1930. Stanford: Stanford University Press.

Thakur, R. 1997. Rewriting Gender: Reading Contemporary Chinese Women. London: Zed Books.

Wolf, M. 1975. "Women and Suicide in China." In Women in Chinese Society, edited by M. Wolf and R. Witke, 111-142. Stanford: University of Stanford Press.

Wood, M. 2020. The Story of China: A Portrait of a Civilisation and its People. London: St Martin's Press.

World Health Organisation 2009. "Women and Suicide in rural China." Bulletin of the World Health Organization 87 (12): 885-964. https://www.who.int/bulletin/volumes/87/12/09011209.pdf?ua=1. https://doi.org/10.2471/BLT.09.101209.

Wreford, J. 2009. "The Pragmatics of Knowledge Transfer: An HIV/AIDS Intervention with Traditional Health Practitioners in South Africa." Anthropology Southern Africa 32 (1-2): 37-47. https://doi.org/10.1080/23323256.2009.11499977.

Yanagisako, S., and C. Delaney, 1992. "Naturalizing Power.” In Naturalizing Power: Essays in Feminist Cultural Analysis, edited by S. Yanagisako and C. Delaney, 1-22. London: Routledge.

Zakaria, F. 2011. The Post-American World. London: Penguin.

Zarrow, P. 1988. "He Zhen and Anarcho-Feminism in China." The Journal of Asian Studies 47 (4): 796-813. https://doi.org/10.2307/2057853.

Zwart, T. 2012. "Using Local Culture to Further the Implementation of International Human Rights: The Receptor Approach.” Human Rights Quarterly no. 34: 546-569. https://doi.org/10.1353/hrq.2012.0020. 